Brazilian Journal of Maize and Sorghum

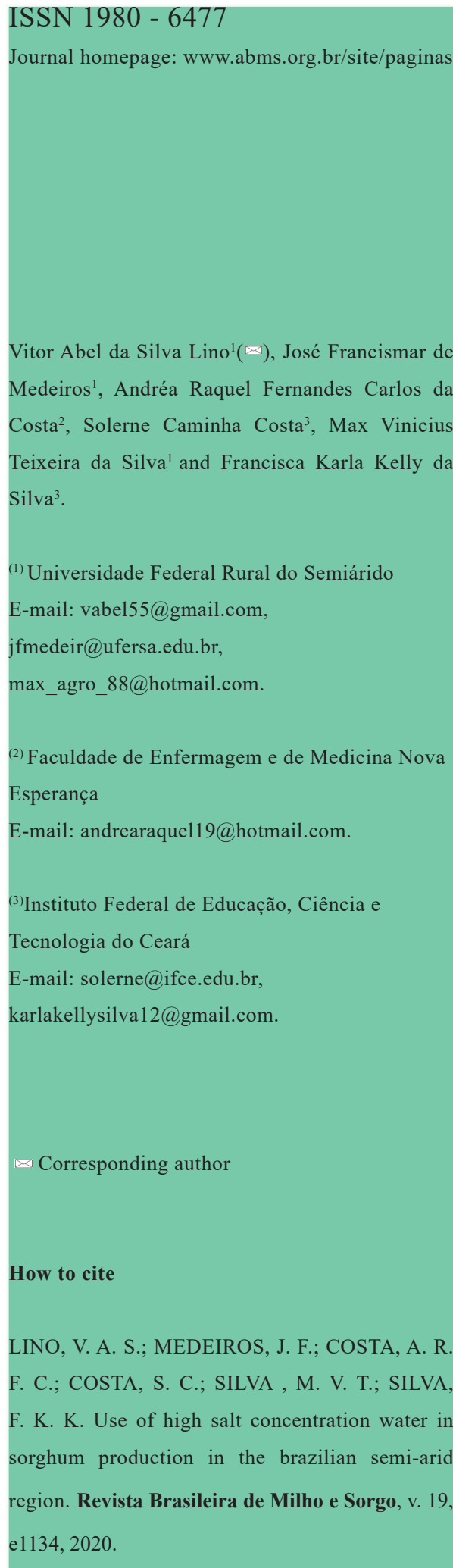

\section{USE OF HIGH SALT CONCENTRATION WATER IN SORGHUM PRODUCTION IN THE BRAZILIAN SEMI-ARID REGION}

\begin{abstract}
In arid and semi-arid regions, due to the low rainfall and high evapotranspiration rate, salts are concentrated in the soil and in the water, causing the salinization of the medium. Irrigation is necessary in these regions, but the volume required by the crops is high. Deficit irrigation is an alternative since it alleviates plant stress, but without affecting the crop yield. Sorghum is a plant that tolerates soil moisture deficit and surplus. The objective of this work was to verify the influence of irrigation water salinity and depth in the sorghum (Sorghum bicolor (L.) Moench) crop in terms of yield. The experiment was conducted from February to May 2016, in the municipality of Mossoro / state of Rio Grande do Norte. The treatments studied consisted of three factors as follows: irrigation water salt concentration (ECw) of 0.8, 2.4, 3.43 and $4.81 \mathrm{dS} \mathrm{m}^{-1}$; irrigation depths of 80,98 and $127 \%$ of ETc applied via drip irrigation; and BRS 506, IPA 2502 and Ponta Negra sorghum cultivars, arranged in a $(4 \times 3) \times 3$ factorial scheme with split plots, cultivars in sub-plots, with four blocks. Supplemental irrigations were implemented, being around $9 \%$ of the crop demand supplied by rainfall that occurred in the period. Soil electrical conductivity presented a reduction tendency when larger water volumes were applied. Irrigation depth and salinity did not influence yield aspects, even with a $20 \%$ reduction in the ideal irrigation depth and water salt concentration of at least $4.81 \mathrm{dS} \mathrm{m}^{-1}$ of electrical conductivity.
\end{abstract}

Keywords: Low quality water, localized irrigation, Sorghum bicolor, deficit irrigation.

\section{UTILIZAÇÃO DE ÁGUA DE ALTA CONCENTRAÇÃO DE SAIS NA PRODUÇÃO DE SORGO NO SEMIÁRIDO BRASILEIRO}

\begin{abstract}
Resumo - Em regiões áridas e semiáridas, devido às baixas precipitações pluviométricas e alta taxa evapotranspirativa, sais se concentram no solo e na água, ocasionando a salinização do meio. A irrigação se faz necessária nestas regiões, mas o volume requerido pelas culturas é alto. Amenizando o estresse das plantas, a irrigação deficitária é uma alternativa, mas sem afetar produtivamente a cultura. O sorgo é uma planta que tolera déficit e superávit de umidade no solo. O objetivo com esse trabalho foi verificar a influência da lâmina e salinidade da água de irrigação na cultura do sorgo (Sorghum bicolor (L.) Moench) no âmbito produtivo. O experimento foi realizado no período de fevereiro a maio de 2016, em Mossoró/RN. Os tratamentos estudados foram constituídos de três fatores: concentração de sais da água de irrigação (CEa) de 0,$8 ; 2,4 ; 3,43$ e 4,81 dS m ${ }^{-1}$, lâminas de irrigação de 80,98 e $127 \%$ da ETc aplicadas via gotejamento e cultivares de sorgo BRS 506, IPA 2502 e Ponta Negra, arranjados em esquema fatorial

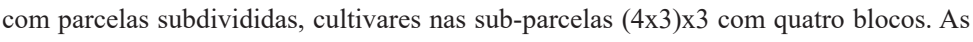
irrigações foram realizadas de forma suplementar, onde cerca de $9 \%$ da demanda da cultura foi suprida pelas precipitações ocorridas no período. A condutividade elétrica do solo tendeu a reduzir quando foram aplicados volumes maiores de água. A lâmina de irrigação e salinidade não influenciaram os aspectos produtivos, mesmo com redução em $20 \%$ da lâmina ideal e concentração de sais na água de pelo menos $4,81 \mathrm{dS} \mathrm{m}^{-1}$ de condutividade elétrica.
\end{abstract}

Palavras-chave: Água de baixa qualidade, irrigação localizada, Sorghum bicolor, irrigação deficitária. 
Nowadays, water scarcity is largely experienced mainly in the Northeast Region of Brazil, compromising the entire production chain. Associated with that, the region faces another problem: the low quality of the water sourced from shallow artesian wells as a result of the high salt content found in most of water.

Sustainable agricultural practices in arid and semi-arid regions depend, among other practices, on the use of irrigation, due to climate instability. However, due to the intense human pressure for good quality water and the increasing need for expansion of agricultural production worldwide, the use of low quality water has increased (NOBRE et al., 2011).

Saline water used in irrigation may represent a risk to the growth and agricultural production of many crops (Islã \& Aragués, 2010; Sales et al., 2015) because of the reduction in the osmotic potential of the soil solution and the possible occurrence of metabolic disorders and imbalance, both caused by concentration of toxic ions in the protoplasm, particularly $\mathrm{Na}^{+}$and $\mathrm{Cl}^{-}$ (Flowers et al., 2014).

Due to the need of increasing production, associated with the restricted water volume available for irrigation, mainly in the semi-arid region, where there is irregular distribution and low volume of rainfall, the deficit irrigation represents an alternative, especially for crops as sorghum (Geerts \& Raes, 2009; Barros et al., 2013).

Sorghum is regarded as a strategic crop for regions or areas with water restriction, due to its higher abiotic stress tolerance, in addition to its moderate salinity tolerance (Dias \& Blanco, 2010). That is the reason why the sorghum is considered an alternative for different products, such as the production of forage material, grains, ethanol and sugar (COSTA et al., 2019).

Therefore, the objective of the present study was to evaluate the yield performance of the various sorghum cultivars when submitted to irrigation water salt concentrations and to variation in the water volume applied.

\section{Material and Methods}

The experiment was conducted from February to May 2016, in the Fazenda Experimental Rafael Fernandes, an experimental farm area located in the Alagoinha community, municipality of Mossoró, state of Rio Grande do Norte, at latitude of $5^{\circ} 03$ ' $37^{\prime} \mathrm{S}$ and longitude of $37^{\circ} 23^{\prime \prime} 50$ 'W.

The Brazilian semi-arid region is characterized by low accumulated rainfall, which is, on average, less than $800 \mathrm{~mm}$ per year, and, in some areas, less than $600 \mathrm{~mm}$ (AB'SABER, 1974; MARENGO et al., 2011). Average temperatures are high, around $25^{\circ} \mathrm{C}$, according to the historical series from 1994 to 2009 (SILVA et al., 2015).

According to the Köppen classification, the climate in the region where the crop was planted is BSwh type (hot and dry), with quite irregular rainfall that varies along the year. The wettest months are February, March and April, while 
the driest months are September, October and November. The average climate conditions for the region are as follows: average air temperature of $27.6^{\circ} \mathrm{C}$, relative air humidity of $68.3 \%$, and rainfall of $756 \mathrm{~mm}$ per year (SILVA, 2014).

In the experimental area, the soil is classified as latossolic Red Yellow Argisol, according to EMBRAPA (2013). Analyses were performed for purposes of soil fertility before the experiment was conducted (Table 1).

The study consisted of three factors as follows: irrigation water salt concentration, irrigation depth and sorghum cultivars, in a $(4 \times 3)$ $\mathrm{x} 3$ factorial arrangement with split plots, where the cultivars were placed in sub-plots, with four replications, in a completely randomized block design.

In regard to irrigation water salt concentration, expressed in electrical conductivity, the water with the lowest concentration $\left(0.8 \mathrm{dS} \mathrm{m}^{-1}\right)$ was from deep artesian well, while the water presenting the highest concentration $\left(5.0 \mathrm{dS} \mathrm{m}^{-1}\right)$ was based on salinity tolerance of sorghum crop for a potential yield of $50 \%\left(\mathrm{ECW}=5.0 \mathrm{dS} \mathrm{m}^{-1}\right)$, according to Ayers \& Westcot (1999).

The water with salt concentration was previously prepared with the addition of salts $\left(\mathrm{NaCl}, \mathrm{CaCl}_{2}-\mathrm{H}_{2} \mathrm{O}\right.$ and $\left.\mathrm{MgSO}_{4}-7 \mathrm{H}_{2} \mathrm{O}\right)$ at a $7: 2: 1$ molar ratio of $\mathrm{Na}, \mathrm{Ca}$ and $\mathrm{Mg}$, which represents the average chemical composition of brackish water in the northeastern semi-arid region. The other two water salt concentrations (2.0 and 3.5 $\mathrm{dS} \mathrm{m}^{-1}$ ) were obtained by mixing these two types of water.

The irrigation depth factor was determined based on crop evapotranspiration estimates (80, 98 and 127\%), using the FAO Penman-Monteith method (ALLEN et al., 2006) to estimate reference evapotranspiration (ETo) (Figure 1), and $\mathrm{Kc}$ estimates using the dual crop coefficient approach. The actual depths applied during the crop cycle were D1 $=306, \mathrm{D} 2=378$ and D3 = $490 \mathrm{~mm}$. For ETo estimation, climate data were collected from a weather station installed in the experimental area, being some of them presented in Figure 1. During the crop irrigation period (90 days), the ETo was $435 \mathrm{~mm}$ and the rainfall was $102.5 \mathrm{~mm}$, distributed in 21 precipitations.

Due to the utilization of mulching, rainwater-use efficiency was limited, with an estimated effective precipitation of $40 \mathrm{~mm}$ obtained through the difference between the ETc estimated in the period and the irrigation depth effectively applied, which was adjusted according to the soil water tension measured with the use of tensiometers, upon occurrence of rainfall.

With regard to sorghum cultivars, the BRS 506, IPA 2502 and Ponta Negra varieties were selected for the study. Ponta Negra stands out as being a promising cultivar, due to its good panicle production, suitability for forage production, and adaptability to the state of Rio Grande do Norte. As to the others, BRS 506 is a saccharine cultivar and IPA 2502 presents high sucrose content, in addition to suitability for grain production.

Soil preparation consisted of plowing, followed by leveling/ harrowing and opening of 
Table 1 - Chemical characteristics of soil and water

\begin{tabular}{|c|c|c|c|c|c|c|c|}
\hline \multicolumn{8}{|c|}{ Soil (0-20 cm depth) } \\
\hline \multirow{2}{*}{ 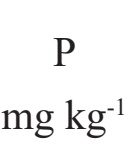 } & $\mathrm{K}^{+}$ & $\mathrm{Ca}^{2+}$ & $\mathrm{Mg}^{2+}$ & $\mathrm{Na}^{+}$ & Sum of Bases & $\mathrm{Al}^{3+}$ & \multirow{2}{*}{$\mathrm{pH}\left(\mathrm{H}_{2} \mathrm{O}\right)$} \\
\hline & \multicolumn{6}{|c|}{$\mathrm{cmol}_{\mathrm{c}} \mathrm{dm}^{-3}$} & \\
\hline 30 & 0.28 & 3.20 & 1.00 & 0.31 & 4.79 & 0.05 & 6.00 \\
\hline \multicolumn{8}{|c|}{ Water Analysis (Deep Well) } \\
\hline \multirow{2}{*}{$\begin{array}{c}\mathrm{CE} \\
\mathrm{dS} \mathrm{m}^{-1}\end{array}$} & $\mathrm{Ca}^{2+}$ & $\mathrm{Mg}^{2+}$ & $\mathrm{Na}^{+}$ & $\mathrm{Cl}^{-}$ & $\mathrm{HCO}^{3}$ & $\mathrm{pH}$ & $\operatorname{RAS}_{\mathrm{ai}}$ \\
\hline & \multicolumn{7}{|c|}{$\mathrm{mmol}_{\mathrm{c}} \mathrm{dm}^{-3}$} \\
\hline
\end{tabular}

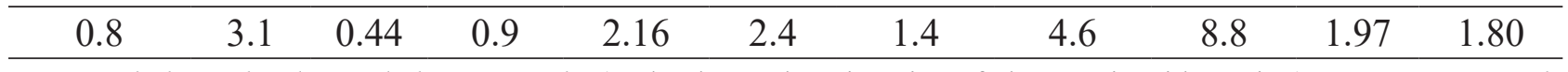

Universidade Federal Rural do Semiárido (Federal Rural University of the Semi-Arid Region), Departamento de Ciências Agronômica e Florestal (Department of Agronomic and Forestry Sciences), Laboratório de Análises de Solo, Água e Planta (Soil, Water and Plant Testing Laboratory).

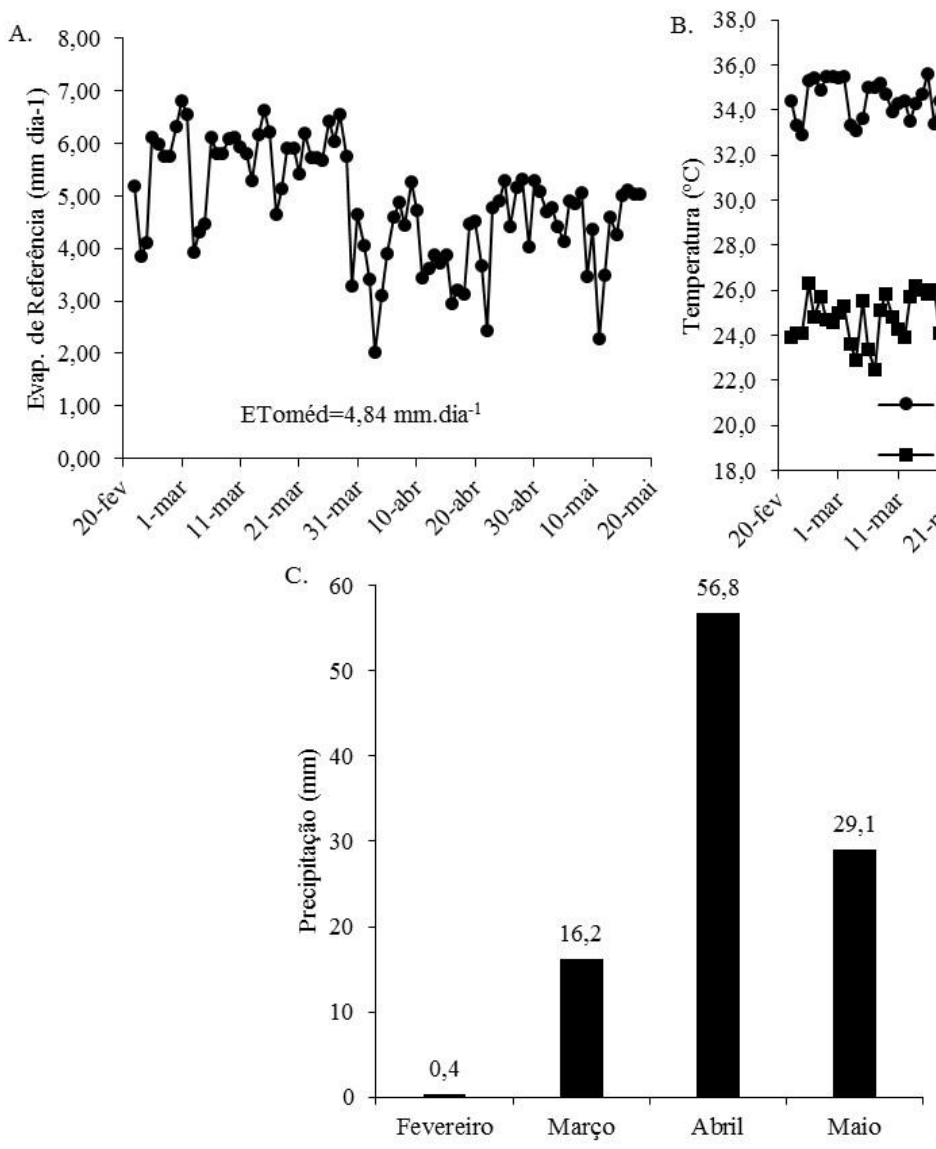

Figure 1 - Reference evapotranspiration values (A.), minimum and maximum temperature (B.), and precipitation (C.) during the experiment period. 
furrows for fertilizer application. The furrows were then closed, thus completing the soil preparation and fertilization, following the recommendation of IPA (2008). The irrigation system was installed, consisting of drip tapes with different flow rates $\left(1.2,1.6\right.$ and $\left.2.0 \mathrm{~L} \mathrm{~h}^{-1}\right)$ so as to meet the irrigation depth requirements.

After that, a $1.0 \mathrm{~m}$ wide, black polyethylene film was installed, covering the entire raised seedbed for weed control and also to prevent soil salts from being directly washed out by rainwater.

The characteristics analyzed consisted in the evaluation of soil electrical conductivity (ECe), through sampling using a Dutch auger in 0-60 $\mathrm{cm}$ profile, obtained through soil saturation extract; total production (TP), obtained through the weighing of stems (culms), collected in 4 linear meters and extrapolated for $\mathrm{t} \mathrm{ha}^{-1}$; total soluble solids in the stem juice (TSS), obtained with the use of bench-top refractometer; stem dry mass production (SDMP) and leaf dry mass production (LDMP), obtained by placing the material sample in a drying oven with forced air circulation at a temperature of $65^{\circ} \mathrm{C}$.

The data were submitted to analysis of variance and regression, where the means of irrigation depth and sorghum cultivar factors were compared through Tukey's test at a 5\% level of significance. The effects of the salt concentration of irrigation water were assessed through regression analysis, partitioning the interaction whenever it was significant at the $5 \%$ level, with the use of the Statistical Analysis System - SAEG software, version 9.1.

\section{Results and Discussion}

After data analyses, in regard to electrical conductivity of the soil saturation extract, in the 0 - $0.6 \mathrm{~m}$ deep layer, a significant effect was identified for the following interactions: irrigation depth and irrigation water salinity, sorghum cultivar and irrigation depth, and sorghum cultivar and irrigation water salinity.

Figure 2A shows the scatter plot for interaction between irrigation depth and irrigation water salinity; and Figure 2B shows the bar graph for interaction between sorghum cultivars and irrigation depth.

Lima et al. (2007), in their study about how the cowpea responds to different irrigation water salinities, found a linear adjustment for ECe, where the increment of 0.5 to $5 \mathrm{dS} \mathrm{m}^{-1}$ resulted in an ECe increase of $105.4 \%$, thus indicating that as the irrigation water salt concentration is increased, there is also an increment in the soil salt concentration.

The same effect was found in the present study for the first two irrigation depths (306 and $378 \mathrm{~mm}$ ), where the increment of $\mathrm{ECw}$ produced an increase in ECe. As to the $490 \mathrm{~mm}$ irrigation depth, there was a quadratic effect, where the maximum value reached $3.43 \mathrm{dS} \mathrm{m}^{-1}$, with an $\mathrm{ECw}$ of $5.5 \mathrm{dS} \mathrm{m}^{-1}$. However, the increment in ECe decreased with the increment of $\mathrm{ECW}$ because, as the soil / water salinity is increased, the plant tends to reduce the transpiration. The result is a non-proportional increase of the leaching water 



Figure 2 - Electrical conductivity of the soil saturation extract (ECe) as a function of irrigation water salinity (ECw) for each irrigation depth studied (A), and as a function of sorghum cultivars for each irrigation depth (B) $(\mathrm{CV} 1=21.19 \%, \mathrm{CV} 2=15.51 \%)$

Differences of cultivars within each irrigation depth are indicated by means followed by uppercase letters; and differences of irrigation depths within each cultivar are indicated by means followed by lowercase letters.

and, with the increment of irrigation depth, there is a consequent increase in the leaching water depth, which causes the soil salt to be washed out.

With regard to the interaction between sorghum cultivars and irrigation depth, there was significant effect of irrigation depths only for BRS 506 cultivar. When the irrigation depth was increased, the production reduced, a behavior characteristic of a saccharine cultivar, and the salinity did not affect the yield of that cultivar.

With respect to yield characteristics of the different sorghum cultivars, there was significant effect for the interaction between sorghum cultivar and irrigation depth as to the total production (TP). In regard to total soluble solids (TSS) and stem dry mass production
(SDMP), there was significant interaction between cultivar and irrigation water salinity. As to leaf dry mass production (LDMP), there was significant interaction between irrigation depth and irrigation water salinity.

Figure 3 shows the result of the interaction between sorghum cultivars and irrigation depth. It can be noted that the highest fresh mass productions are associated with the lowest irrigation depth, regardless of the cultivar under analysis, with reduction as a function of increase in the volume applied, except for IPA 2502, which demonstrates that this cultivar is adapted to both water deficit and small water surplus conditions. Among the cultivars, Ponta Negra was the variety that produced more fresh mass, considering that it is a cultivar intended for production of forage 
material for animal feeding.

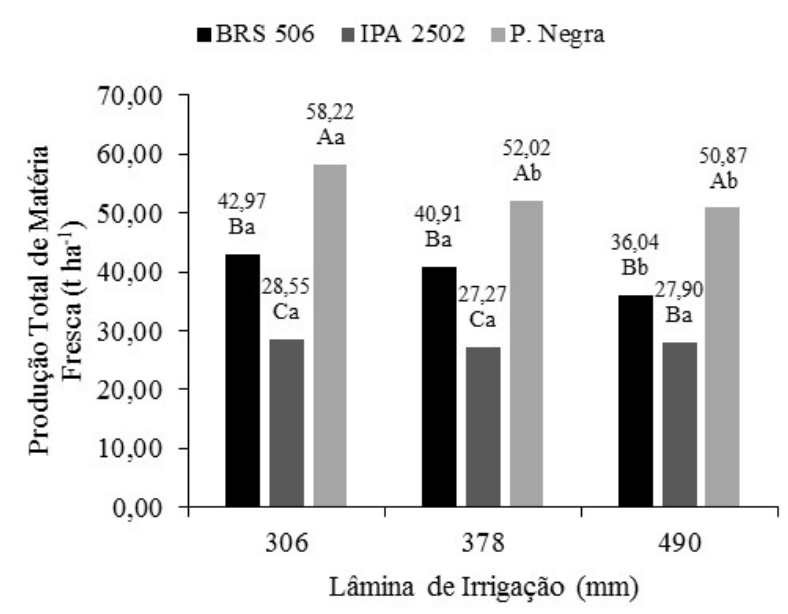

Figure 3 - Total fresh mass production of sorghum cultivars as a function of irrigation depths $\left(\mathrm{CV}_{1}=24.10 \%\right.$ and $\left.\mathrm{CV}_{2}=11.50 \%\right)$

Differences of cultivars within each irrigation depth are indicated by means followed by uppercase letters; and differences of irrigation depths within each cultivar are indicated by means followed by lowercase letters

Vasilakoglou et al. (2011) found different behavior while studying the yield of green sorghum for biofuel production, submitted to increasing soil salinity and irrigation depths. They observed an increment in the fresh mass production from 42.8 to $71.4 \mathrm{Mg} \mathrm{ha}^{-1}$ for the five cultivars analyzed, when the irrigation depth was increased from 120 to $210 \mathrm{~mm}$.

Figure 4 shows the graphical representation of the interaction between sorghum cultivars and irrigation water salinity for the "total soluble solids" characteristic. For the BRS 506 cultivar, there was an increasing linear adjustment, in other words, the increment of irrigation water salinity produced an increase in the total soluble solids of the plant and the values suggested that $17 \%$ were characterized as saccharine cultivars. In regard to Ponta Negra cultivar, the equation adjustment was quadratic, being the minimum point of the curve at a $2.27 \mathrm{dS} \mathrm{m}^{-1}$ salinity, TSS of $10.53{ }^{\circ}$ Brix is found. Therefore, the increment in the TSS can be associated with the plant's attempt to make the osmotic adjustment in its tissues, so as not to lose water to the saline medium it was submitted to.

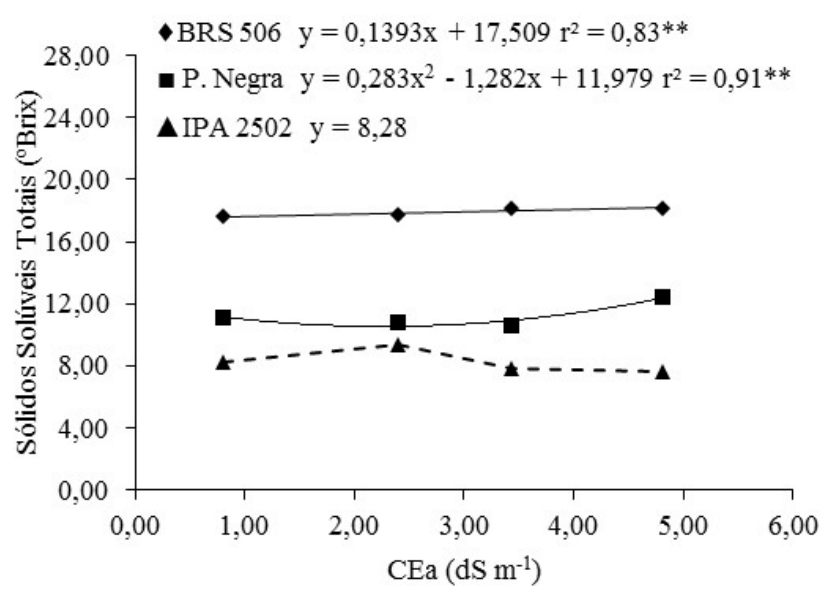

Figure 4 - Total soluble solids of sorghum cultivars as a function of irrigation water salinity $\left(\mathrm{CV}_{1}=22.61 \%\right.$ and $\left.\mathrm{CV}_{2}=13.96 \%\right)$

Parrela et al. (2010), when assessing 25 different sorghum cultivars, found a mean value of $18.62{ }^{\circ}$ Brix for the different locations studied. Pereira Filho et al. (2013), when studying different seeding rates for saccharine sorghum cultivars, found the value of $15.55^{\circ}$ Brix for the BRS 506 cultivar. The highest values were found in BRS 501 and 505 cultivars with 16.04 and 15.93, respectively. 
According to Mamma et al. (1995), the typical range for total soluble solids present in the juice extracted from sweet sorghum varies from 10.5 to $20.7^{\circ}$ Brix, thus the values found for BRS 506 and Ponta Negra cultivars comply with the aforementioned parameters. With regard to IPA 2502 cultivar, due to its low height and the fact that it is intended for grain production, this variety tends to present lower content of total soluble solids in the stem (culm) as it redistributes its sugar to the grain.

Figure 5A shows the graph for stem dry mass production as a function of irrigation water salinity and sorghum cultivars. The BRS 506 cultivar presented a decreasing linear adjustment of stem dry mass production with the increment of irrigation water salinity until the level of 4.81 $\mathrm{d} \mathrm{Sm}^{-1}$. For the other cultivars, there was no equation adjustment, being 6.28 and $2.08 \mathrm{t} \mathrm{ha}^{-1}$ the average values for Ponta Negra and IPA 2502 cultivars, respectively, that is, the ECw does not change the DM accumulation in the stem.

Tavian et al. (2014), while studying the effect of nitrogen fertilization in the biomass accumulation of forage sorghum, found values ranging from 4.2 to $6.9 \mathrm{tha}^{-1}$, depending on the $\mathrm{N}$ dose applied. Silva et al. (2012), when assessing different sorghum genotypes for forage and silage, found average values of $5.57 \mathrm{tha}^{-1}$ among the cultivars.

Figure 5B shows the graph for leaf dry mass production as a function of salinity and irrigation depth. For the irrigation depth of $306 \mathrm{~mm}$, there was a quadratic adjustment with the minimum point of $1.92 \mathrm{t} \mathrm{ha}^{-1}$ at irrigation water salinity of $2.45 \mathrm{~d} \mathrm{Sm}^{-1}$, then increasing up to the maximum salinity studied. For the irrigation depth of 378 $\mathrm{mm}$, corresponding to $100 \%$ of the ETc, there was a quadratic adjustment with the maximum point of $2.18 \mathrm{tha}^{-1}$ at irrigation water salinity of $2.42 \mathrm{~d} \mathrm{Sm}^{-1}$. For the irrigation depth of $490 \mathrm{~mm}$, there was no equation adjustment, with average


Figure 5 - Stem dry mass production (A) and leaf dry mass production (B) as a function of irrigation water salinity (A - CV1 $=31.80 \%$ and CV2 $=21.78 \%$; $-\mathrm{CV} 1=30.46 \%$ and CV2 $=30.46 \%$ ) 
value of $1.82 \mathrm{tha}^{-1}$ among treatments.

Silva et al. (2012) found mean values of 1.21 $t \mathrm{tha}^{-1}$ for leaf dry mass of the sorghum cultivars studied. Tavian et al. (2014) found higher values that reached $6.18 \mathrm{t} \mathrm{ha}^{-1}$. Silva (2015) found that the increase in salt concentration significantly reduced the leaf dry mass. The increment in the irrigation depth, which would be the cause for salts present in the irrigation water to be carried away to more peripheral areas of the wet bulb formed in the soil, was not sufficient to minimize the effect of salt concentration increase on the reduction of leaf dry mass.

\section{Conclusions}

A reduction of at least $25 \%$ in the irrigation depth for sorghum crop enables good yield levels, while excessive irrigation depth is damaging.

The cultivars did not suffer yield loss with the increase of salinity. The Ponta Negra and BRS 506 cultivars presented yield reduction with the increase of irrigation depth.

The increase of irrigation water salinity up to the concentration of $4.81 \mathrm{dS} \mathrm{m}^{-1}$ does not result in significant drop in biomass production of different sorghum cultivars.

\section{References}

AB'SÁBER, A N. O domínio Morfoclimático das Caatingas Brasileiras. São Paulo, IGEOG/ USP, 1974 [Geomorfologia, 43].
ALLEN, R.G.; PEREIRA, L.S.; RAES, D.; SMITH, J. Evapotranspiration del cultivo: guias para la determinación de los requerimientos de agua de los cultivos. Roma: FAO, 2006. 298 p. (Estudio Riego e Drenaje Paper, 56)

AYERS, R.S. \& WESTCOT, D.W. A qualidade de água na agricultura. 2.ed. Campina Grande: UFPB, FAO, 1999, 153p. (Estudos Irrigação e Drenagem, 29 revisado).

BARROS, M. A.; ROCHA, M. M.; GOMES, R. L. F.; SILVA, K. J. D.; NEVES, A. C. Adaptabilidade e estabilidade produtiva de feijão-caupi de porte semiprostrado. Pesquisa Agropecuária Brasileira, v.48, p.403-410, 2013. DOI: $10.1590 / \mathrm{S} 0100-204 X 2013000400008$.

COSTA, A. R. F. C.; COSTA, J. P. N.; MEDEIROS, J. F.; SILVA, M. V. T.; LINO, V. A. S. Desempenho de variedades de sorgo de dupla aptidão submetidas a diferentes lâminas de irrigação com água salina. Revista Brasileira de Milho e Sorgo, v. 18, n. 3, 2019, p. 417-428. DOI: 10.18512/1980-6477/rbms.v18n3p417-428.

DIAS, N. S.; BLANCO, F. F. Efeitos dos sais no solo e na planta. In: GHEYI, H. R.; DIAS, N. S.; LACERDA, C. F. de. Manejo da salinidade na agricultura: estudo básico e aplicados. Fortaleza: INCT-Sal, 2010. p. 129-140.

FLOWERS, T. J.; MUNNS, R.; COLMER, T. D. Sodium chloride toxicity and the cellular 
basis of salt tolerance in halophytes. Annals of Botany, v.115, p.419-431, 2014. DOI: 10.1093/ aob/mcu217.

GEERTS, S.; RAES, D. Deficit irrigation as an on-farm strategy to maximize crop water productivity in dry areas. Agricultural Water Management, Amsterdam, v.96, n.9, p.12751284, 2009. DOI: 10.1016/j.agwat.2009.04.009.

ISLÃ, R.; ARAGUÉS, R. Yield and plant ion concentrations in maize (Zea mays L.) subject to diurnal and nocturnal saline sprinkler irrigations.

Field Crops Research, v.116, p.175-183, 2010. DOI: 10.1016/j.fcr.2009.12.008.

LIMA, C. J. G. S.; OLIVEIRA, F.A.; MEDEIROS, J. F.; OLIVEIRA, M. K. T.; ALMEIDA JÚNIOR, A. B. Resposta do feijão caupi a salinidade da água de irrigação. Revista Verde, v. 2, n. 2, p. 79-86, 2007.

MAMMA D, CHRISTAKOPOULOS P, KOULLAS D, KEKOS D, MACRIS BJ, KOUKIOS E. An alternative approach to the bioconversion of sweet sorghum carbohydrates to ethanol. Biomass-Bioenergy 8:99-103, 1995. DOI: 10.1016/0961-9534(95)00006-S.

MARENGO, J. A.; ALVES, L. M.; BESERRA, E. A.; LACERDA, F. F. Variabilidade e mudanças climáticas no semiárido brasileiro. In: MEDEIROS, S. de S.; GHEYI, H. R.; GALVÃO, C. de O.; PAZ, V. P. da S. (Ed.). Recursos hídricos em regiões áridas e semiáridas. Campina Grande: Instituto Nacional do Semiárido, 2011.

NOBRE, R.; GHEYI, H. R.; SOARES, F. A. L.; CARDOSO, J. A. F. Produção de girassol sob estresse salino e adubação nitrogenada. Revista Brasileira de Ciência do Solo, v. 35, p. 929-937, 2011. DOI: 10.1590/S010006832011000300027.

PARRELLA, R. A. da C.; MENEGUCI, J. L. P.; RIBEIRO, A.; SILVA, A. R. da; PARRELLA, N. L. D.; RODRIGUES, J. A. S.; TARDIN, F. D.; SCHAFFERT, R. E. Desempenho de cultivares de sorgo sacarino em diferentes ambientes visando a produção de etanol. In: CONGRESSO NACIONAL DE MILHO E SORGO, 28.; SIMPÓSIO BRASILEIRO SOBRE A LAGARTA DO CARTUCHO, 4., 2010, Goiânia. Potencialidades, desafios e sustentabilidade: resumos expandidos... Sete Lagoas: ABMS, 2010. 1 CD-ROM.

PEREIRA FILHO, I. A.; PARRELA, R. A. C.; MOREIRA, J. A. A.; MAY, A.; SOUZA, V. F.; CRUZ, J. C. Avaliação de cultivares de sorgo sacarino [Sorghum bicolor (L.) Moench] em diferentes densidades de semeadura visando a características importantes na produção de etanol. Revista Brasileira de Milho e Sorgo, v. 12, n. 2, p. 118-127, 2013. DOI: 10.18512/19806477/rbms.v12n2p118-127.

RICHARDS, L. A. Diagnosis and improvement 
of saline and alkali soils. Washington: United States Department of Agriculture, 1954. 160 p. (USDA. Agricultural Handbook, 60).

SALES, M. A. L.; MOREIRA, F. J. C.; ELOI, W. M.; RIBEIRO, A. A.; SALES, F. A. L.; MONTEIRO, R. N. F. Germinação e crescimento inicial do coentro em substrato irrigado com água salina. Revista Brasileira de Engenharia de Biossistemas, v. 9, p. 221-227, 2015. DOI: 10.18011/bioeng2015v9n3p221-227.

SANTOS, H. G. dos; JACOMINE, P. K. T.; ANJOS, L. H. C. dos; OLIVEIRA, V. A. de; LUMBRERAS, J. F.; COELHO, M. R.; ALMEIDA, J. A. de; CUNHA, T. J. F.; OLIVEIRA, J. B. de. Sistema brasileiro de classificação de solos. 3. ed. rev. e ampl. Brasília, DF: Embrapa, 2013. 353 p.

SILVA, M. L. dos S. Avaliação da tolerância à salinidade em quatro genótipos de sorgo sacarino. 2015. Dissertação (Mestrado) Universidade Federal do Ceará, Fortaleza, 2015.

SILVA, R.; SANTOS, A.; TABOSA, J. N.; GOMES, F.; ALMEIDA, C. Avaliação de diferentes genótipos de sorgo para forragem e silagem. Revista Brasileira de Milho e Sorgo, v. 11, n. 3, p. 225-233, 2012. DOI: 10.18512/19806477/rbms.v11n3p225-233.

SILVA, S. A. O. Análise de variáveis meteorológicas no município de Mossoró-RN
(1970-2013). 2014. 55 f. Monografia (Graduação em Agronomia) - Universidade Federal Rural do Semi-Árido, Mossoró, 2014.

SILVA, F. F. N.; GOMES, A. C. S.; LUCIO, P. S.; ARAÚJO, E. H. S.; SILVA, C. M. S. Estudo de caso: Temperatura média mensal de regiões do litoral e semiárido do nordeste brasileiro (nota de pesquisa). Revista Brasileira de Climatologia, vol. 17, ano 11, p. 282-299, 2015. DOI: 10.5380/ abclima.v17i0.42313.

TAVIAN, A. F. et al., Efeito da adubação nitrogenada no acúmulo de biomassa de sorgo forrageiro, Ciência \& Tecnologia: Fatec-JB, Jaboticabal, v. 6, p. 28-32, 2014.

VASILAKOGLOU, I.; DHIMA, K.; KARAGIANNIDIS, N.; GATSIS, T. Sweet sorghum productivity for biofuels under increased soil salinity and reduced irrigation. Field Crop Research, v. 120, n. 1, p. 38-46, 2011. DOI: 10.1016/j.fcr.2010.08.011. 